\title{
The Impact of Precarious Habitat's Eradication on Socio- Economic and Spatial Changes in State of Bouira, Algeria
}

\author{
Naziha LAMRI*1, Abdelmadjid BOUDER', Abdelhalim BENDIB² \\ * Corresponding author \\ ${ }^{1}$ University of Science and Technology HouariBoumediene (USTHB), Faculty of Earth Sciences, Department of Geography and Land \\ Use Planning, Algiers, ALGERIA \\ 2 University of Oran 2, Faculty of Earth Sciences, Department of Geography and Land Use Planning, Oran, ALGERIA \\ E-mail: lamrinaziha4@gmail.com, abouder@yahoo.fr, halim.bendib@hotmail.com \\ DOI: $10.24193 /$ J SSP.2020.1.03 \\ https:// doi.org/ 10.24193/J SSP.2020.1.03
}

Ke y w o r d s: Algeria, socioeconomic mutation, precarious housing, eradication, urbanization

\begin{abstract}
A B S T R A C T
This paper aims to illustrate and analyze the phenomenon of precarious housing in Algeria, which acknowledges a tragic scale dating back to the colonial period, and continues to increase during the decade 1990-2000 under the pretext of exodus, reaching a threshold of 554,000 precarious dwellings ( $8 \%$ of the total housing stock) according to the only census to date, carried out by the Ministry of Housing and Urban Planning in 2007, of which the state of Bouira marked 15,435 dilapidated dwellings (2.79\%). In this study, we seek to know the role of the urbanization control implemented by the public authorities in order to eradicate precarious housing due to socio-economic changes for their occupants. To this end, theoretical approaches were used to analyze the causes of the phenomenon and temporalize it. A socio-economic survey was also carried out in 4 precarious neighbourhoods, located in two municipalities, Djebahia and El-Adjiba, with 420 dwellings, 574 households and 3013 inhabitants. The results obtained show that, compared to the number of dwellings benefited for the period 2003-2010 (from 19,195 to 53,839), the number of precarious dwellings in the state of Bouira decreased progressively from 33,174 precarious housing units in 1999 to 23,442 units in 2004 to achieve 12,361 units in 2014. This is due to the re-housing intervention (social, participative and rural housing) as well as the rehabilitation program, which has proved successful in some localities and has failed in others.
\end{abstract}

\section{INTRODUCTION}

Housing has long been regarded as one of the basic needs for human life and the primary element for the well-being of families. Housing is a form of shelter; it exists in order to ensure safety and protection for people and families from rain, cold, wind, etc. (Paquot, 2005). Unfortunately, around one billion people (924 million) in the world live in poor conditions, in degraded, unhealthy, unworthy, and precarious housing (Union Nation Habitat, 2003).

Like other countries, Algeria is also experiencing these conditions of precarious or unsuitable housing that is characterized by physical fragility, overcrowding and lack of viability networks, etc. (Meskaldji, 1994). According to exceptional census carried out by the Ministry of Housing and Urban Planning (MHU) in 2007, the number of precarious housing units recorded is more than $1 / 2$ million $(553,441)$ (People's Democratic Republic of Algeria, 2014), which represents $8 \%$ of the total housing stock (Official Journals of People's Democratic Republic of Algeria, 2010; Safar-Zitoun and Hafiane, 2012). The number is quite large and the consequences will be more tragic. Algerian authorities issued a national alert to tackle this precarious housing phenomenon and try 
by all financial, material and human means to eradicate these unhealthy dwellings and ensure a dignified life for this category of population (Naceur, 2013). However, a study conducted by the Ministry of Housing concluded that this operation proved to be costly and inefficient for the public budget [In the policy of improving precarious housing. About 10 years ago and again in June 1996, the GoA (Government of the People's Democratic Republic of Algeria) attempted to eradicate precarious housing mainly in the Algiers region. But this policy proved to be costly and inefficient; population displacement strategies were not satisfactory, and slums continued to grow] (Ministry of Housing and Urban Development, 1998).

Indeed, according to several studies in the field, this situation has a significant effect on the urban phenomenon and the daily life of inhabitants. It is in particular the unscheduled urban sprawl of peripheral areas (Dridi et al., 2015) that is feeding the feelings of anguish and stress (Baker et al., 2016), the deterioration of security and the invasion of violence and crime ( $\mathrm{El}$ Kadi, 1997) and the outbreak of diseases related to poor hygiene conditions and extreme poverty, namely typhoid fever (Shah et al., 2012; Corner et al., 2013; Dewan et al., 2013; Bendib et al., 2016), the cholera (Ali et al., 2015) and cutaneous leishmaniasis (Akhavan et al., 2014; World Health Organization, 2017). Various studies have been carried out, and different approaches have been proposed to deal with the phenomenon of precarious housing (El Kadi, 1997; Benarde, 2007; Shier et al., 2016; Quicke and Green, 2017; Ziersch, 2017).

In this article, we examine the problem of precarious housing in the state of Bouira, approaching some clustered cities, to know their daily suffering and by studying the various concerns of the local authorities in order to make socio-economic and spatial changes in the region.

\section{THEORY AND METHODOLOGY}

\subsection{Description of study area}

The state of Bouira is situated in the northcentral region of Algeria and considered as an important regional transit (Fig. 1).

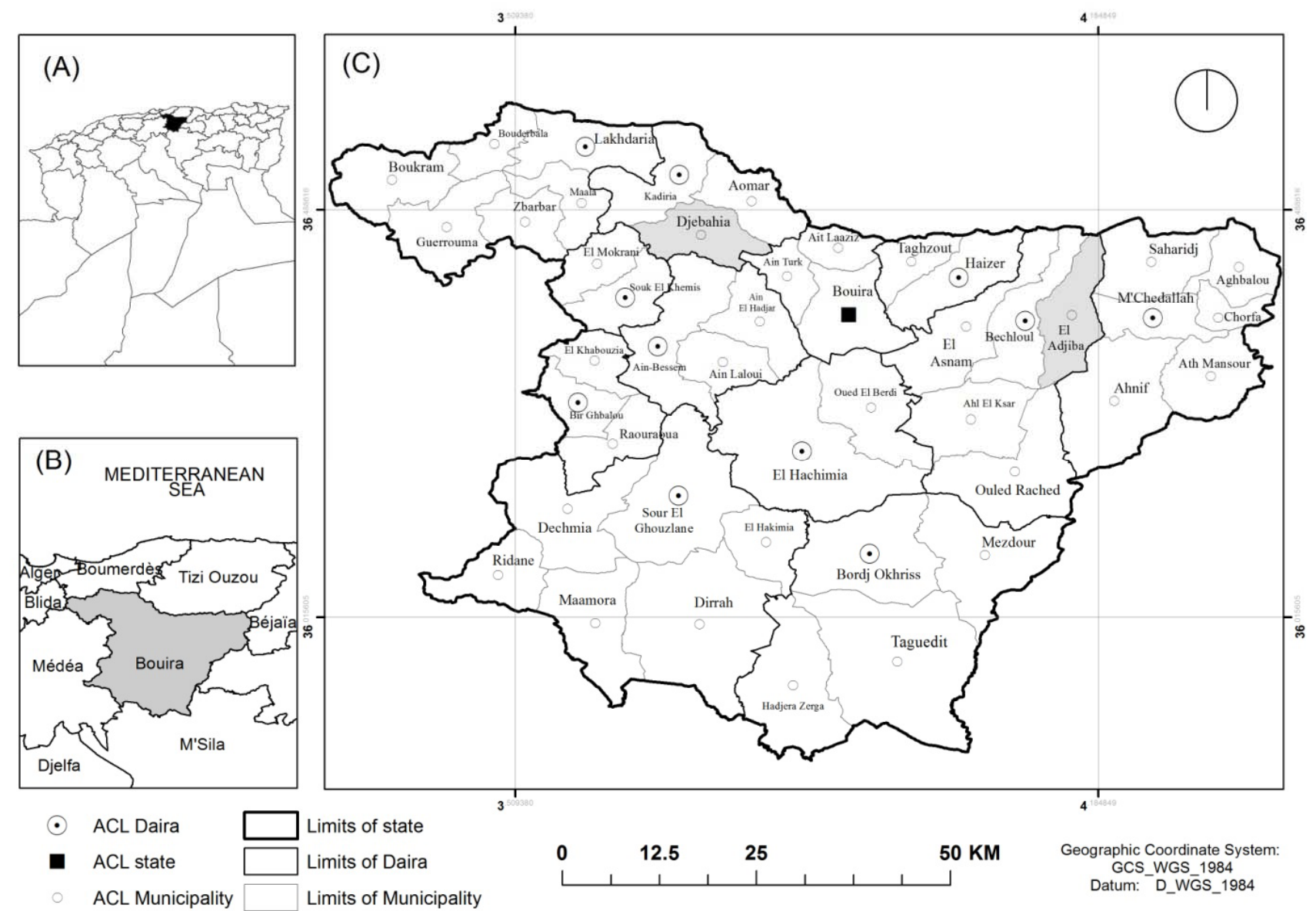

Fig. 1. A map of the study area. State Bouira (A), State boundary (B) and the administrative division of the state Bouira (C).

We also try to answer the following question: What are the different socio-economic and spatial changes concerning the eradication of precarious housing in the state of Bouira?
Our methodology is based on theoretical approaches to analyze the causes of the phenomenon and temporalize it and to know, on the other hand, the role of the control of urbanization in the eradication of 
precarious housing. To this end, statistical analysis, interpretation and comparison of data were employed. For this purpose, different kind of data, collected from various sources were used, consisting of information provided by the census carried out by the Ministry of Housing and Town Planning (2007), data obtained from different agencies and departments on urban planning, land use, housing and public facilities and finally, data collected through socio-economic surveys carried out in 4 precarious neighbourhoods.

It is limited in the north by the states of Boumerdes and Tizi-Ouzou, in the south and southwest by the states of M'sila and Médéa, in the east and south-east by the states of Bejaia and Bordj Bou Arreridj and in the west by the states of Blida and Médéa. It is the result of the administrative division established by the ordinance no. 74-69 of 02 July 1974 relative to the territorial reorganization of departments (Department of Planning and Town and Country Planning, 2007).

It covers an area of $4454 \mathrm{~km}^{2}$, representing $0.19 \%$ of the national territory and it consists of 12 subdivisions and 45 municipalities.

Bouira is characterized by heterogeneity of natural environment comprising five (05) morphological zones: the eastern end of the Atlas Blidéen, the southern slope of the mountains Djurdjura, the central lowland, the Bibans, and the south Bibanic lowland (Fernane and Tessa, 2015). This morphological diversity affects the climate, which is characterized by harsh winter and hot summer, with strong annual amplitudes reaching $5^{\circ}$ and $30^{\circ}$. The climatic and morpho-structural conditions have enabled the existence of an appreciable hydrographical network (Oued Isser, Sahel, Oued Lakhal, etc.).

According to the National Meteorological Office (ONM) of Algeria, the state of Bouira is characterized by favourable rainfall, especially in the northern part (Atlas Blidéen and the south slope of Djurdjura) with fairly large rainfalls that exceed 600 $\mathrm{mm} /$ year. While on the summits of Djurdjura, precipitation can easily exceed $2000 \mathrm{~mm} /$ year, in the central lowland, precipitation values range only from 400 to $600 \mathrm{~mm} /$ year. The lowest volumes are recorded in the south Bibanic lowland, where sometimes reach only $200 \mathrm{~mm}$ to $300 \mathrm{~mm}$ /year (the southern end).

These climatic conditions can be a disadvantage against fragile dwellings, heavy rains being able to easily destroy them and make the living conditions of inhabitants unbearable and painful.

\subsection{Research methodology}

In this study, we aimed to analyze and map the phenomenon of precarious habitat in the state of Bouira. To achieve this, our methodology is based on theoretical approaches to analyze the causes of the phenomenon and temporalize it and to illustrate, on the other hand, the role of urbanization control in the eradication of precarious housing. To this end, statistical analysis, data interpretation and comparison were used. Different kinds of data from various sources were used.

Firstly, we based on the results of the analysis on data related to precarious housing provided by the only census to date, carried out by the Ministry of Housing and Town Planning in 2007. They enabled us to study the phenomenon in terms of number, type and causes of spread in all localities in Algeria. Then, in order to study the phenomenon of precarious housing and to conclude on the eradication interventions operated by the local and national public authorities, the present study also suggests the collection of data such as urban planning, land use, housing and public facilities, etc. To this end, different agencies and departments were visited.

In addition to these two types of data, socioeconomic surveys were carried out in four precarious neighbourhoods grouped together, located in two municipalities (Djebahia and El-Adjiba), representing rural and urban areas. Our surveys included 420 dwellings, 574 households and 3013 inhabitants. We aimed to perceive the difficulties encountered and reveal the characteristics of precariousness concerning the dwelling (type, acquisition, rooms, conveniences, water supply, lighting mode, fuel used, and connection to sanitation equipment) and household structures (number, function, income, cultural level, age, etc.).

In the end, data obtained was organized ArcGIS 10.1 software and statistical tables (MS Excel), which led to the spatialization and mapping of the phenomenon, as well as to the development of statistical and comparative analyses.

\subsection{Demographic and socio-economic study of Bouira department}

The advantage of a demographic study is to provide classification elements and bring out data that is of the greatest interest in analysing equipment and service needs (Wetton, 1987). As it can be said, population is subject to changes in number, and regression or increase may be anticipated. These changes are determined by different socio-economic factors or internal and external migration flows.

The State of Bouira has a large population, estimated at 704,336 inhabitants in 2008 . The majority of its inhabitants are between 15 and 35 years old, which represents $57.28 \%$ of the total population of the state of Bouira. The growth of this young population represents a human potential for state development. The inter census growth rates are respectively 3.43\% in 1987, 1.59\% in 1998 and 1.0\% in 2008 (Planning and Spatial Planning Department of Bouira, 2010). 
However, this situation also puts enormous pressure on housing demand.

A statistical assessment conducted by the National Office of Statistics shows that the State of Bouira become a site of attractiveness and an engine of economic growth, where the majority of economic activities are focused in major sectors, namely trade with 8421 entities (51.05\%), services with 6294 entities (38.17\%), industry with 1604 entities (9.73\%) and constructions with 174 entities (1.05\%) (ONS, 2012).

While the population seems to increase from one year to another thanks to the economic development in the major sectors aforementioned and the improvement of the living environment (health, employment, education, etc.), the housing stock has tripled. A considerable increase from 48,996 dwellings in 1977 amounted to 78,090 in 1987, and from 102,248 in 1998 , to 126,399 in 2008 , and to 149,447 dwellings in 2010. However, the overall number of housing stock reached the threshold of 158,030 dwellings in 2014.

By comparing the evolution between the number of population and the housing stock of the state over time (1977, 1987, 1998, 2008 and 2014), we can see that the two factors are intimately linked. This analysis, confirms that there is a very significant correlation estimated at $99.85 \%$ between the number of population and the housing stock (Fig. 2).

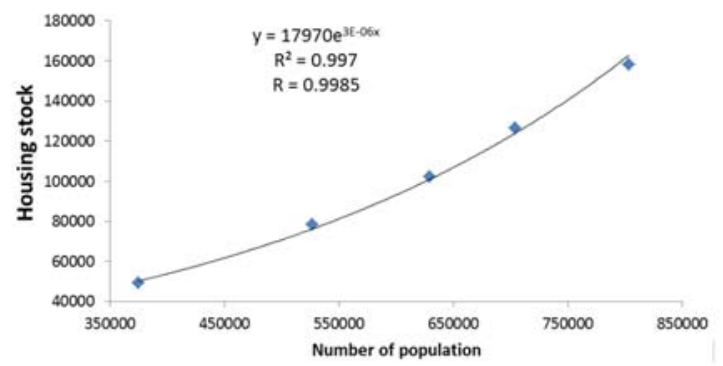

Fig. 2. Correlation between the evolution of population and housing stock.

Moreover, the exponential form of this curve provides us with more important information; it clearly justifies the evolution of housing stock at a faster rate than that of the population.

On the other hand, although housing stock has increased, it is still not enough for the rapidly increasing population (Tebbouche et al., 2017) and a significant number of dwellings in a degraded state - a total of 15,435 precarious dwellings (according to the 2007 Census conducted by MHU). This figure is totally different from the number of precarious habitats identified during the last census of 2008 which showed only 2619 units. In 2008, they only took into account houses constructed of heteroclite materials, whereas the MHU in 2007 considered that any dwelling not in conformity with urban planning rules and possibly threatening the lives of its occupants was a precarious dwelling; hence, this discrepancy in the records of the two censuses.

\subsection{Identification of the precarious habitat phenomenon in Bouira state}

In Algeria, the phenomenon of precarious housing (Fig. 3) dates back to the colonial period, [The minister of housing and town planning said that this phenomenon appeared in the 1960s, and that it took an alarming proportion in the 1990] (Ministry of Housing and Urban Planning, 2009).
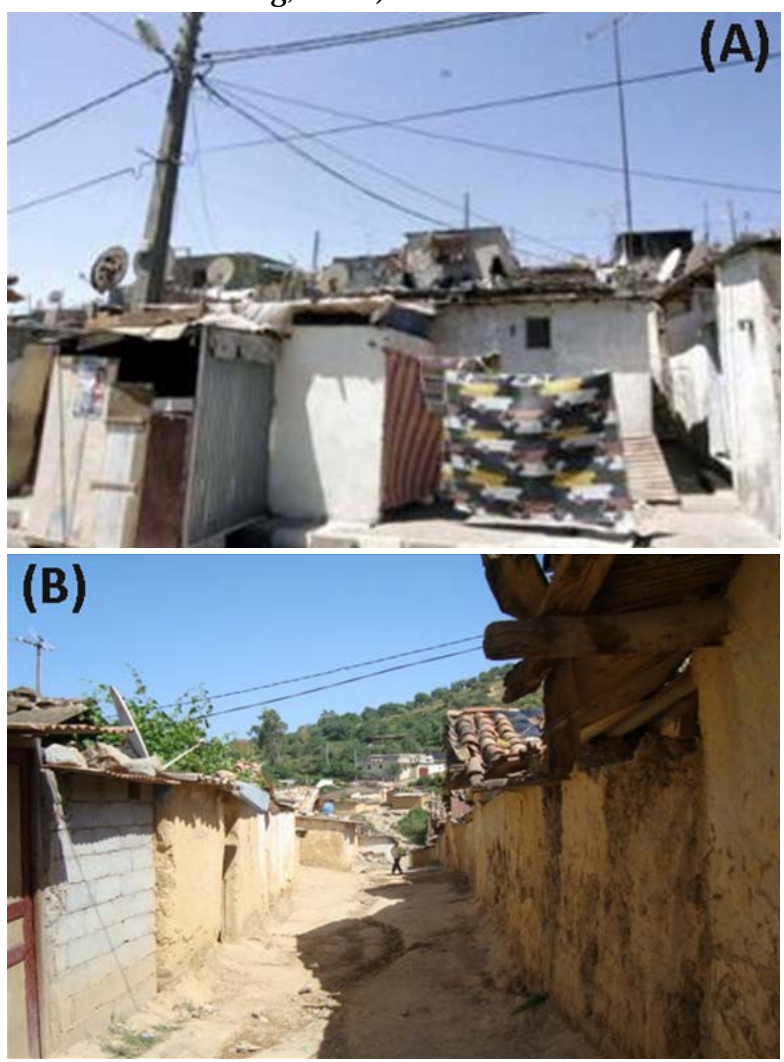

Fig. 3. Types of precarious housing. Slums of Algeria 2010 (A), and houses of the colonial period (B).

The phenomenon continued to considerably increase during the 1970s and 1980s. During the period 1966-1977, characterized by a national policy of planned economy and industrialization in the main urban centres, about 1.7 million of the rural population moved to cities, at a rate of about 130,000 per year (Cote, 1996). Furthermore, due to the displacement of the rural population towards cities during the black decade (1990-2000), because of the security conditions that Algeria has known, people began to build houses illegally, using materials that did not comply with building regulations (heterogeneous materials and recoveries, tarnish, sheets, etc.).

Algeria has considered that any dwelling lacking the basic necessities of life (water, electricity, sanitation, hygiene, etc.) is precarious as well as unhealthy, and does not represent a valid shelter for an individual or a family because of its fragile building materials and poor living conditions, and the discomfort experienced by their inhabitants (Arimah, 2010). 
A census of the precarious housing stock across the national territory was carried out in 2007, enabling its quantification, which was of 553,441 precarious constructions (Ministry of Housing and Urban Development, 2007), distributed in all states of Algeria, as there were three precarious habitats, according to building materials.

\subsubsection{Shanty town dwellings}

This category of dwellings represents housing facilities made from heteroclite materials (sheets, cardboard, etc.), installed on sites that lack all amenities and viabilities (Lloyd, 1979). This type of habitat is generally found around large cities. According to the census of the precarious habitat carried out in 2007, it was estimated that there were 92,129 slums in Algeria, spread all over the national territory.

\subsubsection{Spontaneous dwellings}

These constructions are made spontaneously with durable materials (bricks, cinder blocks, etc.), but their urban technical characteristics do not meet the standards or rules of a suitable dwelling (Mouats, 2015). The census of the precarious habitat recorded a number of 279,464 houses built of bricks and cinder blocks.

\subsubsection{Degraded earthen houses}

These are constructions made of durable materials but having suffered pathological effects of degradation, they are mainly made of degraded earth (Toub in Arabic) during the colonial period. They are [regrouping camps that were created in order to deprive the FLN (National Liberation Front) of the support of the population] (Vidal-Naquet, 2002).

The other kind of precarious housing is the one that is located in the highlands and particularly in the great south, called ksours. [These superb earthen buildings played a fundamental role for centuries; they were the fortified dwellings of the lords. Isolated and located on a dominant position, they expressed the authority of the Caïds (representatives of the sultan) or Pacha (governors of an imperial city)] (Boutabba et al., 2016).

These dwellings take their colours from their land of origin, which goes from ochre to red (Meddah et al., 2007). According to the census carried out in 2007, the number of precarious constructions built with degraded clay is of 181,848 (Fig. 4).

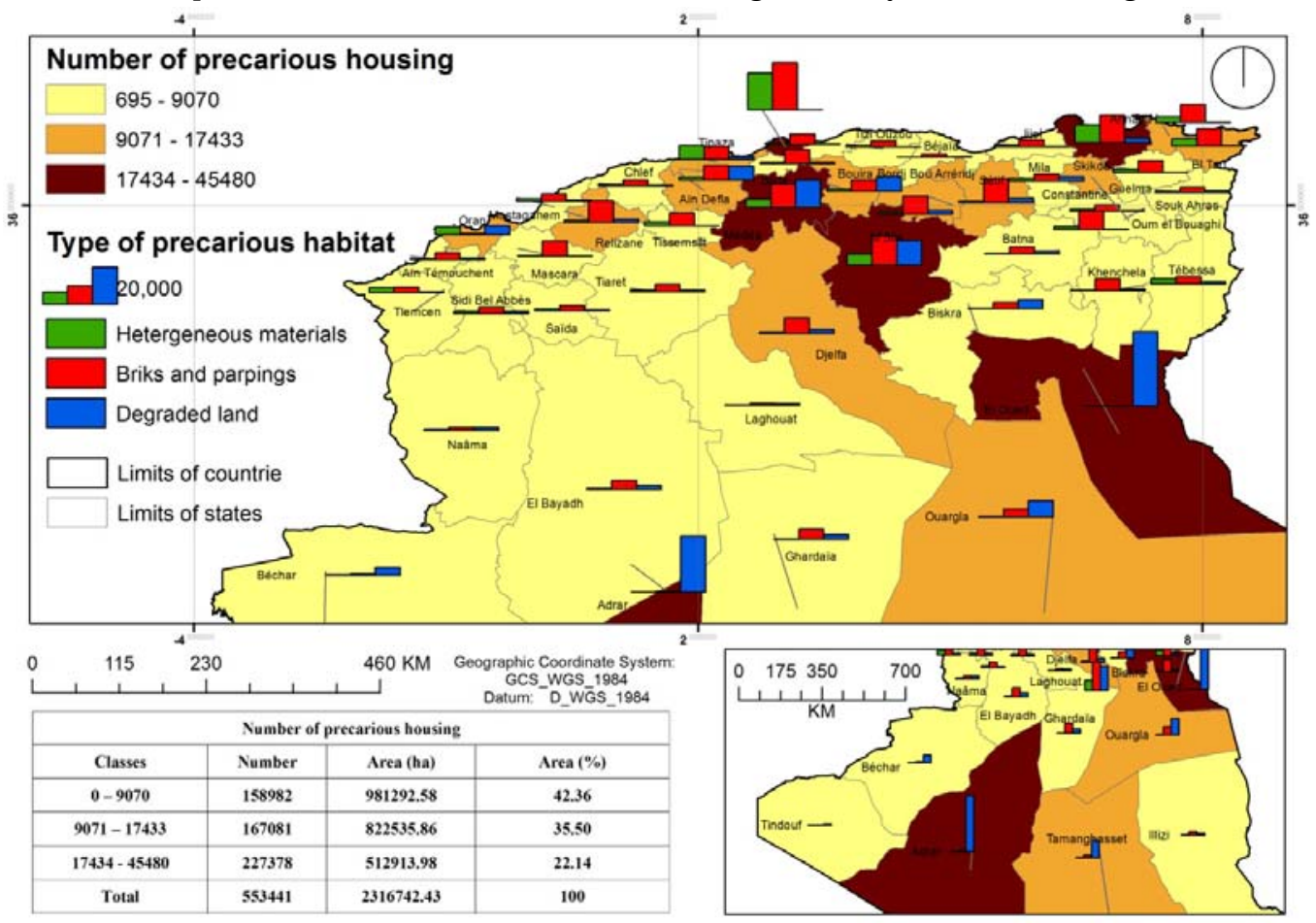

Fig. 4. Distribution of precarious habitat in Algeria by states in 2007.

The state of Bouira has been suffering from the spread of precarious housing for decades, which led to all kinds of degradation of the living environment. It has a large number of precarious habitats, which is 15,435 dwellings, including $2.79 \%$ of the total national precarious housing stock. We can see three types of precarious habitats in the Figure 5:
- 1143 dwellings constructed of heteroclite materials;

- 6005 houses in brick and cinder block;

- 8287 houses built with degraded clay;

Furthermore, our field surveys concluded that this phenomenon has affected the majority of the locations of the state. Indeed, the main sociological and 
demographic factors that have favoured the appearance

mentioned in the sections below. of precarious neighbourhoods in the State of Bouira are

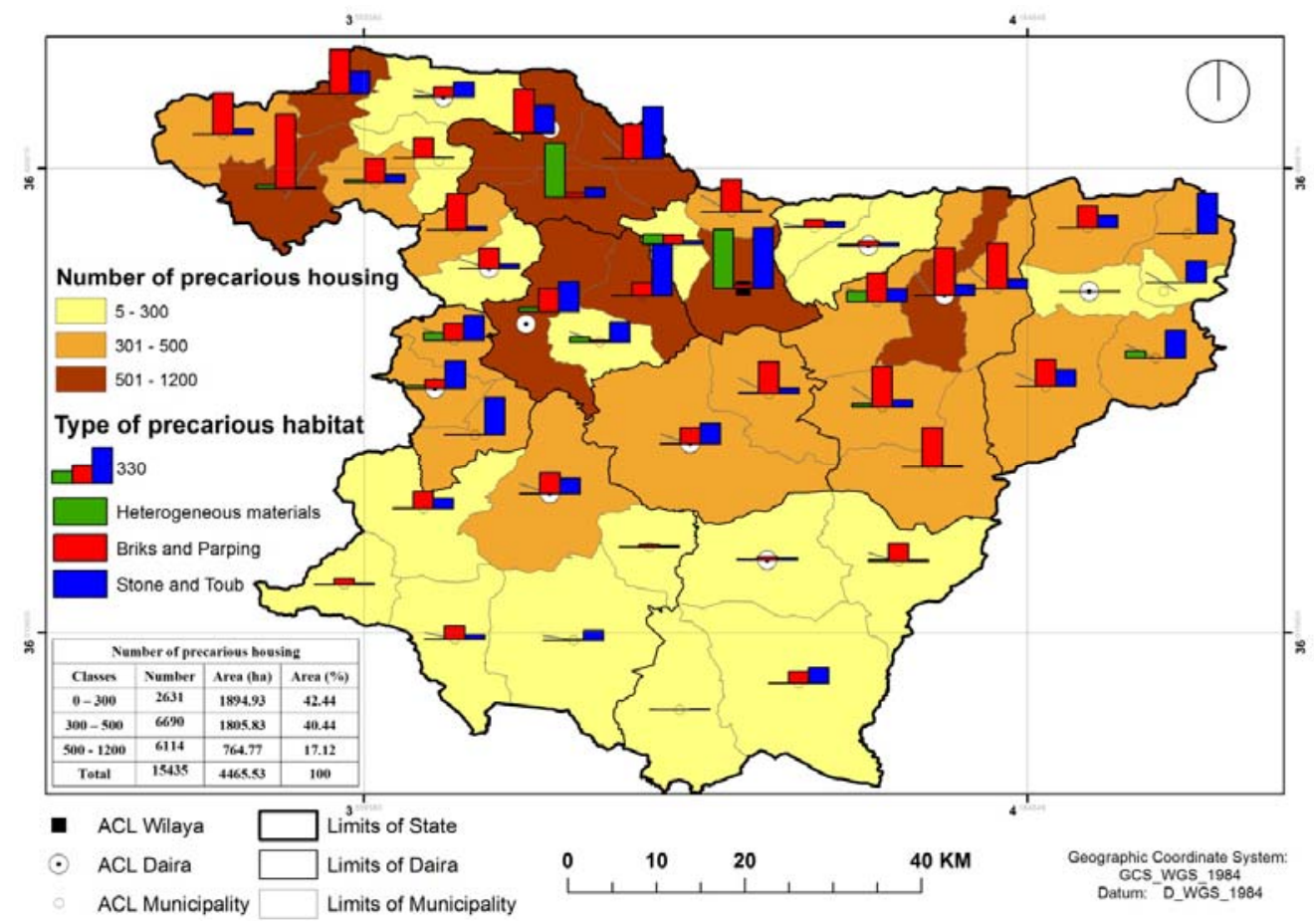

Fig. 5. Distribution of the different types of precarious habitat of Bouira, in 2007, by municipality.

\subsubsection{Demographic factors and rural exodus}

After independence, the state of Bouira experienced a sharp increase in population (Table 1), which explains why inhabitants started to leave rural areas to settle in big cities in search of employment, better living conditions and a good education for children.

Table 1. Distribution of the precarious housing stock by regions in 2007. Source: Urban Planning and Construction Department of the state de Bouira, 2007.

\begin{tabular}{|c|c|c|}
\hline Region & $\begin{array}{l}\text { Total no. of } \\
\text { precarious housing }\end{array}$ & $\begin{array}{c}\text { Site } \\
\text { number }\end{array}$ \\
\hline Urban area & 5,010 & 157 \\
\hline Rural area & 10,425 & 515 \\
\hline Total of state & 15,435 & 702 \\
\hline Total of population & 105,287 & - \\
\hline $\begin{array}{l}\text { Occupancy rate by } \\
\text { dwelling }\end{array}$ & $6.80 \%$ & - \\
\hline
\end{tabular}

The same exodus appeared during the decade of 1990-2000, when many families fled their homes due to insecurity, to settle in the vicinity of large agglomerations in order to find peace, quiet and security.

\subsubsection{Historical factors}

The majority of these substandard dwellings, built with degraded clay (8287 homes) in the state of
Bouira, go back to the colonial period in 1958, led by the French authorities to control the war of national liberation (Vidal-Naquet, 2002). After independence, people continued to live in the same dwellings, and quality would continue to decline.

The majority of these dwellings (10425) are located in rural areas, spread over 515 sites (68\%), most of which are buildings in degraded clay, stones, Toub or bricks and blocks. On the other hand, those made of heterogeneous materials are mostly located in or around large cities (urban areas) representing 32\%. It turns out that $15 \%$ of the total population of the State of Bouira occupies these fragile constructions, totalling 105,287 inhabitants. This important number alerts authorities to find solutions to stop the spread of the phenomenon, or eradicate it permanently.

\section{RESULTS AND DISCUSSION}

\subsection{Socio-economic study of residents living in precarious buildings and their problems}

In order to better assimilate the scourge of the precarious habitat installed in the State of Bouira, it is necessary to get in touch with its inhabitants and have a closer look at the different struggles each of them goes through, and find out the characteristics of precariousness and the poverty they encounter.

That is why we carried out a socio-economic survey in 4 precarious districts, located in two different areas; the municipality of Djebahia in the subdivision of 
Kadiria, and the municipality of El Adjiba in the subdivision of Bechloul.

These four districts are divided as follows: 2 districts in rural areas and 2 in urban areas (the main town of the municipality), 420 homes and 574 households and 3013 inhabitants. This is enough to see the different problems faced by these citizens, however, it is difficult to study the 702 sites of 15,435 houses distributed over a large area $\left(4,454 \mathrm{~km}^{2}\right)$ in a short period of time.

Three types of construction were identified during our field investigation:

(1) Residential dwellings: there are 311 dwellings, which represent $74 \%$ of the buildings;

(2) Spontaneous dwellings: 70 dwellings, representing $16.7 \%$ of the buildings;

(3) Slums: this type of precarious constructions is made of heteroclite materials (sheets, cardboard, etc.); there are 39 homes, or $9.3 \%$.

Of the 420 houses studied, it is essential to know the legal status of the exploitation of these inferior-level dwellings. We note that $68.8 \%$ are inherited houses, occupied by the same families since 1958, or just after independence; $19.8 \%$ of these fragile dwellings are purchased by new families from the previous owners, and $10.5 \%$ are illegally constructed homes, using heterogeneous materials or cinder block, for security reasons (internal exodus) or lack of refuge. Ironically, there are parasitic people who want to benefit from social housing and wait until the time of the census in order to benefit from a new house. For instance, we can mention the people who left their homes in mountainous or remote areas during the black decade of 1990-2000. They refuse to return to their homes despite the completion of that period, in order to benefit from social housing. Like other people, who bring back a family member from another region to be registered in the new municipality in order to benefit from free social housing.

As shown in figure 6, it can be seen that $95.5 \%$ of citizens state that they have sanitation, $89 \%$ of citizens state that their houses are connected to electricity, $69 \%$ of these precarious dwellings are supplied with drinking water, $41.7 \%$ of these inhabitants report having an independent kitchen and $5 \%$ of all these precarious dwellings have bathrooms but, only after they extended their dwellings using bricks or cinder blocks.

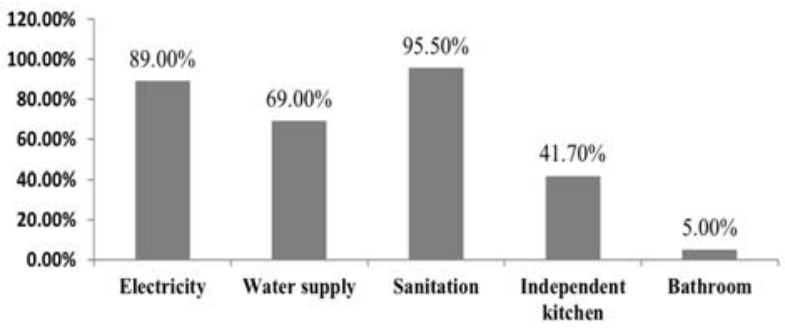

Fig. 6. Amenities of precarious housing.
This field investigation shocked us because we felt the misfortune of these inhabitants, mainly because of their terrible lack of water (Fig. 7, Fig. 8); where $58.8 \%$ of total housing-located in rural areas-get their water supplies from spring water sources using pipes in an uncontrolled manner, $23.6 \%$ of these precarious dwellings are supplied from surrounding neighbourhoods and $17.6 \%$ use portable tanks.

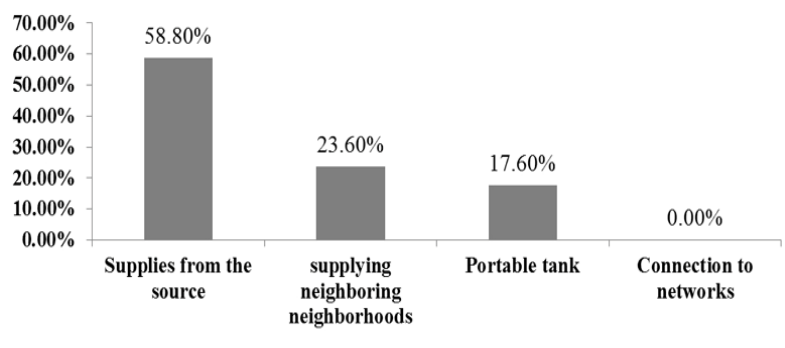

Fig. 7. Drinking water supply in precarious housing. Source: Socio-economic survey, 2014.

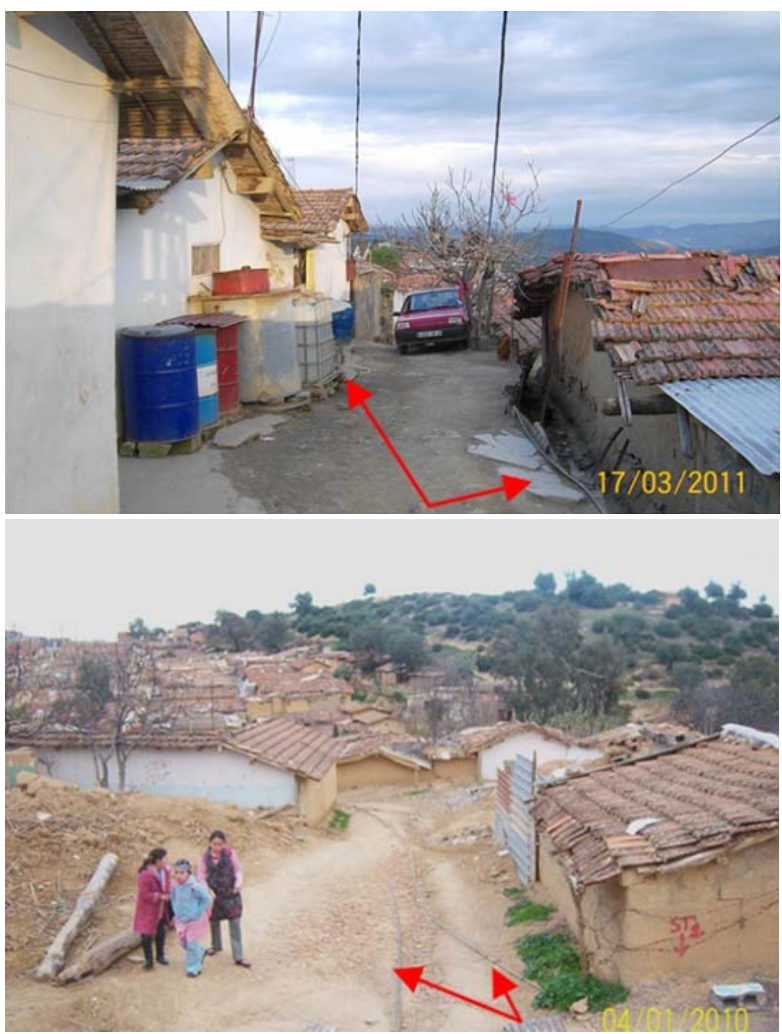

Fig. 8. Drinking water supply in precarious housing.

\subsection{Household characteristics}

The majority of household heads lived in precarious housing before 1962 (54.7\%). However, $37.6 \%$ of the household heads interviewed came from the same municipality and settled in these buildings for security reasons. It is also noted that $5.6 \%$ of all household heads came from neighbouring municipalities.

According to Table 2, the total population of 3013 inhabitants is divided into: 
- between 20-44 years old; this is the age category with the largest number of inhabitants (1380 people, or $45.8 \%)$;

- under 19 years of age; about 1049 inhabitants, representing 34.82\%;

- over 45 years of age; the rest of the population, representing $19.3 \%$.

Table 2. The structure of inhabitants of precarious housing, by age. Source: socioeconomic survey, 2014.

\begin{tabular}{c|rr} 
Age categories & \multicolumn{1}{|c}{ Number } & Share (\%) \\
\hline $0-9$ & 444 & 14.7 \\
$10-19$ & 605 & 20.1 \\
$20-44$ & 1380 & 45.8 \\
$45-64$ & 414 & 13.7 \\
65 & 170 & 5.6 \\
Total & $\mathbf{3 0 1 3}$ & $\mathbf{1 0 0}$
\end{tabular}

We can conclude that the population residing precarious settlements is young. More than $80 \%$ of the total population is under 44 years of age, $20.96 \%$ represents the unemployed population in the studied sites of the precarious habitat. It is higher than the unemployment rate of the department of Bouira, which is of $13.71 \%$ (Table 3 ).

We were able to conclude the various problems and difficulties encountered by the occupants either inside or outside the impure housing, on site, namely:
(1) the physical fragility of the precarious habitat (cracks on walls and ceilings);

(2) overcrowding (more than two people per room);

(3) difficulties inside the dwelling (humidity, discomfort, lack of space, infiltration of rainwater, absence of the ventilation system, etc.);

(4) absence of drinking water, and the majority of households get their water from mobile sources or tanks that reach the neighbourhoods;

(5) lack of connection to a sanitation network, so the majority connect to septic tanks or dump their waste in the open;

(6) the long distances that link these dwellings to schools (primary, middle or secondary) or with the health centre (distances of more than $3 \mathrm{~km}$ );

(7) lack of basic infrastructure (alleys are narrow and impracticable especially in winter because of the mud and excessive runoff in the middle, and along the alleys).

On the health and psychological level, unworthy housing represents dangerous factors, causing many diseases such as: respiratory difficulties chronic colds, development of asthma attacks), skin diseases (mycoses, allergies), withdrawal, depression, shame, feelings of frustration or injustice, etc (Craddock, 2004).

Table 3. The labour force and the employed population. Source: socioeconomic survey, 2014.

\begin{tabular}{|c|c|c|c|c|c|c|c|c|}
\hline \multirow{2}{*}{$\begin{array}{c}\text { Total } \\
\text { population } \\
\text { no. }\end{array}$} & \multicolumn{2}{|c|}{$\begin{array}{l}\text { Population at } \\
\text { working age }\end{array}$} & \multicolumn{2}{|c|}{ Active population } & \multicolumn{2}{|c|}{ Occupied population } & \multicolumn{2}{|c|}{$\begin{array}{l}\text { Unemployed } \\
\text { population }\end{array}$} \\
\hline & no. & $\%$ & no. & $\%$ & no. & $\%$ & no. & $\%$ \\
\hline 3013 & 2082 & 69.1 & 916 & 44 & 724 & 79.04 & 192 & 20.96 \\
\hline
\end{tabular}

\subsection{Resorption strategies for precarious habitat in the department of Bouira}

The eradication of precarious housing has been a top priority for the Algerian authorities, so it has been provided with all public and private financial resources to fight this phenomenon, which continues to increase as time passes by (Semmoud, 2009).

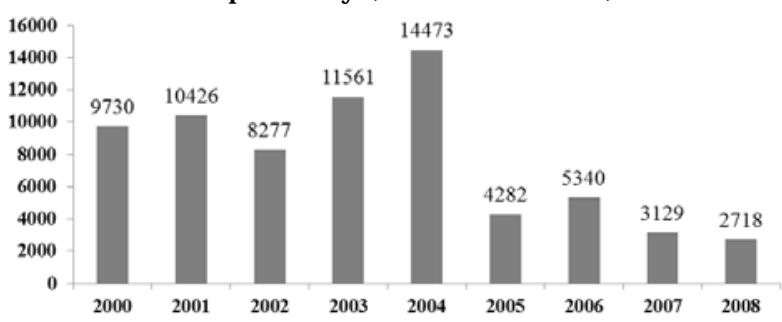

Fig. 9. The number of precarious housing demolished during the period 2000 to 2008 . Source: National Centre for Documentation, Press, Image and Information, 2010 .
Figure 9 shows the number of precarious homes demolished throughout Algeria. These demolitions are made following intense government programs such as the RHP (Resorption of Precarious Housing) dated J uly 9th, 1998 (Ait Mokhtar, 2016).

It is also articulated by a loan agreement between the World Bank and Algeria, and affects twelve states: Algiers, Annaba, Blida, Bouira, Constantine, Guelma, Medea, M'sila, Skikda, Oran, Tipaza and Tebessa. It is defined by a three-year contract worth \$120 million, equivalent to about 5,500 million Algerian dinars, financed by the World Bank for Reconstruction and Development. It is aimed for resorption of precarious housing and should provide about 15,000 housing units. Thus, the state contributes with $70 \%$ of the total cost and the remaining $30 \%$ is the responsibility of the beneficiaries (Safar-Zitoun and Hafiane, 2012). 
This program failed because of the following arguments:

(1) these dwellings have become a new kind of precarious housing, only in a more orderly and legal manner;

(2) the avoidance of precarious neighbourhood's demolition after the re-housing of households encourages new families to settle down, so the phenomenon is renewed;

(3) short-term experience.

The Algerian strategy has affected all localities at the national level (Yousfi, 2016), so even the State of Bouira had its place in development, as it has benefited from a special program (RHP) or other rehousing project.

As presented in figure 10, the number of these precarious dwellings decreased progressively due to the efforts of public authorities aiming at putting an end to these problems. Nevertheless, housing stock has gone from 23,442 precarious housing units in 2004 to 15,434 units in 2007 and 15,072 units in 2008, and in 2014, it finally reached 12,361 precarious housing units in the State of Bouira.

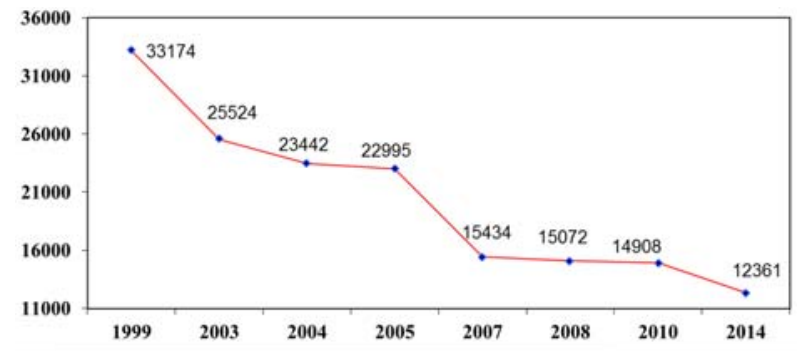

Fig. 10. The evolution of the precarious park in the state of Bouira from 1999 to 2014. Source: Department of Planning and Town and Country Planning, 2014.

Among the forms of interventions on the precarious habitat in the state of Bouira, two procedures are presented below:

\subsubsection{Eradication of precarious housing and rehousing procedures}

In 1996, a new housing policy was planned by the Ministry of Housing to relaunch a huge housing program to reduce the precariousness of many homes. According to the Director of Urban Planning (DUC) of the State of Bouira, 6300 precarious dwellings were demolished during the period 1999-2009 and 6876 households were relocated under the program for the rescue of precarious housing (RHP) financed by the World Bank.

Following the failure of the RHP program financed by the World Bank, the State of Bouira was obliged to look for other ways to eradicate this kind of unworthy housing (Fig.11). Initially, 2000 social housing units (rental or participatory) were planned during the five-year period 2005-2009 for the renovation of the housing sector in the department, and to build new housing for low-income households in all localities of the State of Bouira.

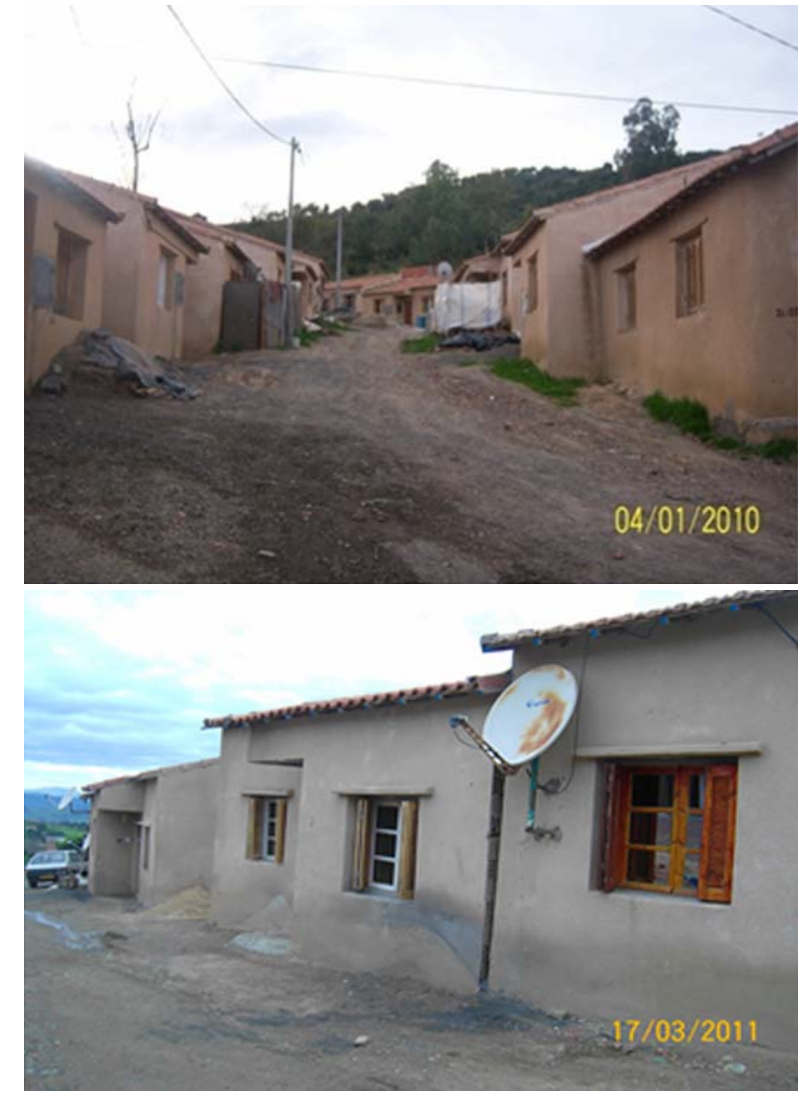

Fig. 11. Housing constructed under RHP state of Bouira.

The public authorities of Bouira State programmed an additional quota for the construction of social housing in the benefit of residents inhabiting these unhealthy shacks each year.

Of the 9525 social housing units in the framework of RHP registered in the territory of Bouira State, 2714 dwellings have been completed, 3395 dwellings are still under construction, and 3416 dwellings have not yet started to be constructed. The State of Bouira has important material and human assets (building materials, skilled workforce, etc.), enormous capacities for an urban renewal of the entire administrative territory.

Above all, the local public authorities and the authorities of Algeria have established a strict and objective strategy in order to satisfy this marginalized category of people, along with the objective of fighting illegal dwellings.

Over a period of 7 years, Bouira State has benefited from a major housing programme. The number of housing units increased from 19,195 in 2003 to 53,839 in 2010 , distributed among the different types of programs, the most important being the Rural Housing Habitat. The latter has undergone rapid growth regarding the number of registered dwellings, due to the high demand on this kind of selfconstruction, which is based on state aid. 
This aid increased from $(200,000$ DA$500000 \mathrm{DA})$ to $700,000 \mathrm{DA}$ in 2010 , in addition that the beneficiary can benefit from a bank credit for the interior and exterior construction.

The state of Bouira has also given importance to social housing intended for low-income citizens and those residing in precarious facilities. Indeed, this growth in the number of dwellings registered for this type of social housing is noticeable, from 5,492 in 2003 to 12,475 dwellings in 2010.

The state of Bouira has made enormous efforts to eradicate precarious dwellings, especially those which are spatially grouped. Overall, the state has 79 clustered locations of precarious housing, spread over the urban and rural areas. Hence, interventions in these districts were as follows: 20 eradicated sites (demolition of precarious housing); 27 restructured sites (site development) and 32 leftover sites.

From 79 precarious housing, the state of Bouira has programmed 27 sites for rehabilitation and renovation based on land regularization, positive modification of their habitats, as well as promoting public activities and services.

When these sites are unfit for construction or are subject to easement and other natural or technological constraints, they will be assigned to urban functions of general interest or public utility (plaza, garden, nursery, green spaces, etc.) (Fig. 12).

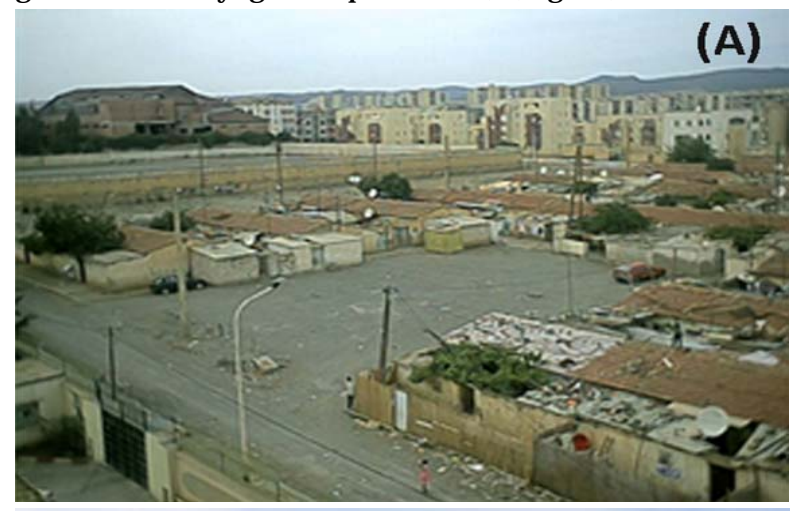

(B)

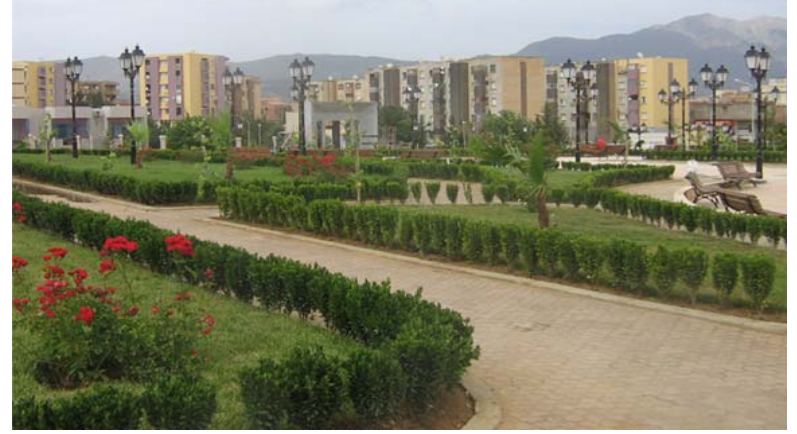

Fig. 12. Precarious district Guizi in municipality of Bouira, before the demolition (A), transformation of the precarious district Guizi to a fabulous garden (B).

The urbanizing and constructible sites occupied by barracks will be valued in accordance with 26 the provisions of the planning and urban planning instruments. The aim is to carry out housing operations or service packages and to integrate the accompanying equipment needed to improve the urban context in which these sites are located.

On the other hand, development plans for rehousing sites in collective or individual dwellings must include all the accompanying amenities in order not to reconstitute "dormitory" dwellings. We can give the example of a precarious district (SAS) which is located in the municipality of Djebahia, composed by 54 dwellings. Then, in 2009, officials decided to eradicate it and rehouse the inhabitants in a new district which is shown in Figure 13.
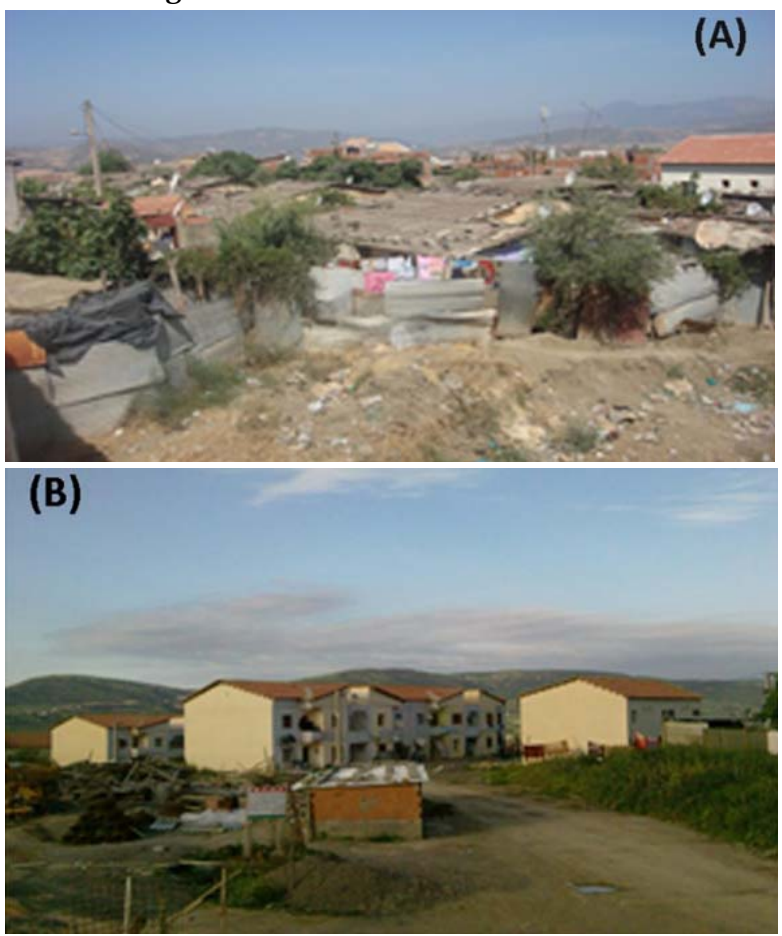

Fig. 13. Precarious quarter SAS (A), 62 social rental housing (RHP) to relocate the residents of the precarious neighbourhood SAS (B).

The eradicated site has a large surface area $\left(4321 \mathrm{~m}^{2}\right)$, so it must be recovered for the implementation of a large housing operation. The decision makers of the municipality have decided to transform the site into a subdivision, which contains all the modern assets to meet the needs of the citizens (housing, parking, green space, etc.). It is a development of 6 buildings containing 50 housing units and 19 commercial facilities.

\subsubsection{Rehabilitation and restructuring of precarious neighbourhoods}

The rehabilitation or restructuring of precarious settlements represents the objective of development projects for housing improvement and renovation, in order to enhance the living conditions of the communities, through the positive modification of 
their habitats, activities, public services, streets, etc. All in a very short time compared to the spontaneous evolution of cities.

"Chahid Berdel" district, which is located in the capital of El Adjiba's municipality, is a proper example. The restructuring operation and prevention of this district was entrusted during the year 2000 to a technical study office to establish a socio-economic and spatial survey, in order to develop a plan adequate to the needs of citizens. Thus, people in this neighbourhood were able to get their property deeds, so they could build their houses.

\subsection{Prospects and future programs for the eradication of precarious habitat}

The Algerian state reserved a financial envelope of more than 3700 billion dinars, equivalent to 50 billion (milliard) dollars, for the realization of two million new housing facilities during the period 20102014, while working to facilitate citizens direct assistance with the aim of promoting access to home ownership and the rehabilitation of urban tissue (El Moubarek and Daoud, 2014).

This five-year program 2010 - 2014 projects a total of 2,000,000 homes in Algeria (Abbas, 2011) which consists of 500,000 public rental housing units, 300,000 housing units in the context of resorption of precarious housing, 500,000 state-supported promotional homes, 700,000 rural dwellings assisted by the state.

Some 1.2 million dwellings that were programmed to be delivered over the five-year period (2010-2014), while the remaining 800,000 units were completed between 2015 and 2017. Of the 2,000,000 housing units planned for completion during the period 2010-2014, the department of Bouira benefited from a number of 33,000 housing units, allocated to a total envelope of 77 billion dinars (Direction of Habitat and Town Planning, 2016). On the other hand, these 33,000 dwellings are distributed as follows: 9,000 social rental housing units (LSL), 4,000 social participations (LSP) and 20,000 housing units in the form of rural housing subsidies.

On the other hand, the action plan of the government for 2015 - 2019, based on the axis dedicated to housing, committed to [continue the efforts made in the habitat of all types. Through the diversification of the supply of dwellings in such a way as to ensure that the entire registered demand, including that required for the reduction of the precarious habitat, is covered] (Algerian Democratic and Popular Republic RADP, 2014).

This program has traced the realization of 1.6 million housing in all the localities of Algeria distributed as follows; 800,000 public rental housing units (LPL), 400,000 homes for sale or for rent (LV),
400,000 rural housing and 50,000 public housing units (LPP) (Algerian Democratic and Popular Republic RADP, 2014).

Furthermore, socio-economic surveys conducted in precarious neighbourhoods require a proven level of expertise that is characterized by informal relationships. They must lead to the classification of families according to their level of income. However, low-income families (less than 24,000 DA or 179.62 Euro) benefit from social housing, according to the interministerial order issued in 2002, establishing the modalities of application of Executive Decree $\mathrm{N}^{\circ}$. 94-308. Nevertheless, middle-income households benefit from state-assisted participatory housing (700,000DA or 5238.80EUR).

Unfortunately, re-housing districts (social housing) are often located at the periphery of urban areas, which have failed in various development operations, containing narrow houses. This situation provokes a feeling of malaise and marginalization among the occupants, which leads to the emergence of numerous socio-economic problems, namely unemployment and crime. In another context, a phenomenon of gentrification has appeared in these neighbourhoods, since many families sell or rent their houses to other people, who are moderately rich or welloff. However, public authorities must think about the proper development of re-housing estates before households settle down and create employment as well as entertainment spaces.

\section{CONCLUSIONS}

The government's willingness to progressively, but resolutely, tackle the eradication of precarious housing has been given priority in recent years; during the period between 1999 and 2008. Thus, the balance sheets studied recently and relating to the period 19992008 , show that the pace of delivery of public housing and equipment has continued to accelerate throughout this period, making it possible to reduce perceptibly the existing deficits. With a financial envelope of more than 1700 billion DA mobilized for the realization of the various programs, 1520845 housing units were finally delivered

However, in spite of the will of the public bodies to put an end to the precarious habitat, the populations targeted by these different operations are far from being satisfied. Families of several members often refuse to leave their former homes. The argument that is always given is related to the fact that new houses are too small to fit large families.

The authorities of the department of Bouira have declared in several events that the housing sector will have priority and that it will have its share financially and technically to achieve a satisfaction in the habitat, so that each household would have a 
reliable housing, built in compliance with the rules of urbanism and architecture. Indeed, local authorities have also promised to put a stop to the phenomenon of precarious housing in all the localities of the department in a fair and progressive way.

\section{RECOMMENDATION}

In order to achieve the desired goal, it is necessary to follow the following measures:

(1) The immediate demolition of all precarious buildings whose inhabitants are rehoused by the local authorities, assisted by all the services concerned.

(2) Any new creation of a precarious or spontaneous dwelling must be immediately eradicated.

(3) Strengthening actions to improve the living conditions of citizens residing in difficult and precarious conditions.

(4) Accelerate studies and approval of development plans and town planning in all municipalities (master development plan (PDAU), land use plans (POS), subdivision permits, etc.); to achieve this, local authorities are encouraged to use new techniques such as GIS and remote sensing, which would make land use control more facile.

(5) Carry out a global and definitive resorption treatment of the precarious habitat sites, considering practical actions as follows: (a) the identification of all the precarious sites across the region, (b) develop studies that illustrate the housing situation, including in scattered areas, with physical and urban planning constraints; (c) elaboration of maps delimiting the sites and specifying the existing constructions according to their state of precariousness and the measures of protection taken against possible extensions, (d) carry out a census of the households of each site, supplemented by socio-economic studies, and provide details on the occupied buildings.

(6) Elaborate technical studies for the development and reconstruction of sites and develop programs in accordance with the provisions of the urban planning instruments in force.

(7) Continue project implementation to complete the five-year program or other programs so that completion is timely and avoid delays in projects due to administrative, financial or technical problems.

(8) Promote assistance to rural housing to encourage people to settle in the countryside, taking into account the improvement and development of these rural areas.

\section{REFERENCES}

Abbas H. (2011), Housing production as an indicator of socio-economic changes: Case of Constantine (magister thesis). University of Constantine, Constantine, Algeria.
Omar A. M. (2016), L'évolution de la Réforme des Politiques Publiques dans les Pays du Maghreb; cas Algérie (Evolution of Public Policies Form in Maghreb Countries; the case of Algeria). Academic J ournal of Human and Social Studies, 16, 3-15. URL: https:// www.univ-chlef.dz/RATSH/la_revue_N_16/ Article_Revue_Academique_N_16_2016/Science_eco _admin/Article_FR 1.pdf. Accessed on 12.06.2018

Akhavan P., Karimi M., Pahlavani P. (2014), Risk Mapping of Cutaneous Leishmaniasis via a Fuzzy C Means-based Neuro-Fuzzy Inference System. International Archives of the Photogrammetry, Remote Sensing and Spatial Information Sciences. XL-2/W3, 19- 23. DOI: https:// doi.org/ 10.5194/ isprsarchives-XL2-W3-19-2014.

Algerian Democratic and Popular Republic (RADP) (2014), Plan d'action du Gouvernement pour la mise en œuvre du programme du Président de la République (Government Action Plan for the Implementation of the Presidential Program). URL: http:/ / www.mf-ctrf.gov.dz/ presse/ planaction2014fr.

pdf. Accessed on 04.07.2019

Ali M., Nelson A. R., Lopez A. L., Sack D. A. (2015), Updated Global Burden of Cholera in Endemic Countries. PLoS Neglected Tropical Diseases, 9(6), 1-13. DOI: https:// doi.org/ 10.1371/journal.pntd.0003832

Arimah B. C. (2010), The Face of Urban Poverty: Explaining the Prevalence of Slums in Developing Countries. Working paper, World Institute for Development Economics Research (UNU-WIDER). URL: https:// www.wider.unu.edu/ sites/ default/ files/ wp2010-30.pdf. Accessed on 23.11.2019

Baker E., Laurence L. H., Bentley R., Andrew B. (2016), Poor housing quality: Prevalence and health effects. Journal of Prevention \& Intervention in the Community, 44(4), 219-232. DOI: 10.1080/10852352. 2016.1197714

Benarde M. A. (2007), Our precarious habitat: it's in your hands. J ohn Wiley \& Sons. New Jersey. ISBN: 978-0-470-09969-8.

Bendib A., Dridi H., Kalla M., Baziz N. (2016), Analyse spatiale de la vulnérabilité à la fièvre typhoïde dans la ville de Batna (Est de l'Algérie) (Spatial analysis of typhoid fever vulnerability in the city of Batna (eastern Algeria))._Environnement, Risques \& Santé, 15(3), 228-237. DOI: 10.1684/ ers.2016.0861

Boutabba H., Mili M., Boutabba S. D. (2016), L'architecture domestique en terre entre préservation et modernité: cas d'une ville oasienne d'Algérie "Aoulef" Domestic architecture in the ground between conservation and modernity: If an oasis city in Algeria "Aoulef". Journal of Materials and Environmental Science 7(10), 3558-3570. URL: https://www.jmater environsci.com/ Document/vol7/vol7_N10/388-J MESBoutabba.pdf

Corner R. J ., Dewan A. M., Hashizume M. (2013), Modelling typhoid risk in Dhaka Metropolitan Area of 
Bangladesh: the role of socioeconomic and environmental factors. International J ournal of Health Geographics, 12, 1-15. DOI: https:// doi.org/ 10.1186/ 1476-072X-12-13

Cote M. (1996), The Algerian space, the beginnings of a development. Edition Masson- Armand Colin. Paris. ISBN: 2225851468

Craddock S. (2004), City of plagues: disease, poverty, and deviance in San Francisco. University of Minnesota Press. ISBN: 9780816630486.

Department of Planning and Town and Country Planning (DPAT) (2007), Monography of the Department of Bouira.

Department of Planning and Town and Country Planning (DPAT) (2014), Monography of the Department of Bouira.

Dewan A. M., Corner R., Hashizume M., Ongee E. T. (2013), Typhoid Fever and Its Association with Environmental Factors in the Dhaka Metropolitan Area of Bangladesh: A Spatial and Time-Series Approach. PLoS Neglected Tropical Diseases, 7, 1-13. DOI: https:/ / doi.org/ 10.1371/journal.pntd.0001998

Direction of Habitat and Town Planning (2016), Report on the state of the housing sector, Department of Bouira.

Dridi H., Bendib A., Kalla M. (2015), Analysis of urban sprawl phenomenon in Batna city (Algeria) by remote sensing technique". Annals of the University of Oradea, 25(2), 211-220. DOI: 10.13140/RG.2.1.4273.7527 El Kadi G. (1997), Quality of life and precarious housing in some countries of the Arab world. Space, populations, societies, 1, 35-47. URL: https://www.persee.fr/ doc/ espos_0755-7809_1997_num_15_1_1788. Accessed on 15.04.2018.

El Moubarek M., Daoud F. (2014), Appreciation of the effort of public finances, through the different plans, in the development of the economy. Algebraic economy. J ournal of Strategy and Development, 4(6), 6-34.

Fernane A., Tessa A. (2015), Contribution of the contemporary centrality to the sustainable territorial development and the new systems of governance: The case of regional metropolis, Papers of Geographic Seminar, 40(1), 115-124.

Lloyd P. C. (1979), Slums of hope? Shanty towns of the third world. Manchester. Palgrave Macmillan. ISBN: 10:0312729634.

Meddah A., Bertrand H., Elmi S. (2007), La province magmatique de l'Atlantique central dans le bassin des Ksour (Atlas saharien, Algérie). The central Atlantic magmatic province in the Ksour basin (Saharan Atlas, Algeria). Comptes Rendus Geoscience, 339(1), 2430. DOI: https:// doi.org/ 10.1016/j.crte.2006.10.006

Meskaldji G. (1994), The spontaneous habitat in Algeria: the case of Constantine. Construction of the Geographical Institute of Reims Algerian Studies, 85, 83-91.

Ministry of Housing and Urban Development (1998), Precarious habitat resorption program, environmental impact assessment: Final report. URL: http:// www-wds.worldbank.org/ servlet/WDSContent Server/WDSP/IB/ 2000/02/24/ 000009265_398070 2115618 / Rendered / PDF / multi_page.pdf. Accessed on 22.04.2018

Ministry of Housing and Urban Development (2007), Habitat bulletin, 2, 1-63. URL: http:// www.anurb.dz/ Revues/ Revue\%20de\%20l'habita t\%206.pdf. Accessed on 14.02.2017

Ministry of Housing and Urban Planning (2009), Information Review, 3.

Mouats W. (2015), Les Bidonvilles a Skikda, Pathologie de l'Habitat (The slum at skikda, pathology habitat). Sciences \& Technologie, 41, 53-60. URL: http:// revue.umc.edu.dz/index.php/ d/ article/ view/ 170 2/ 1822

Naceur F. (2013), Impact of urban upgrading on perceptions of safety in informal settlements: Case study of Bouakal, Batna. Frontiers of Architectural Research, 2(4), 400-408. DOI: https://doi.org/ 10. 1016/j.foar.2013.06.004

National Centre for Documentation, Press, Image and Information (CNDPII) (2010), Major projects in Algeria, housing and construction sector, $\mathrm{N}^{\circ} 1$. URL: http:// www.cndpi.dz/ cndpii/index.php? lang=fr. Accessed on 17.03.2020

National Office of Statistics (ONS) (2012), First Economic Census: final results of the first phase. Statistical Collections n.172 / 2012. Series E: Economic Statistics. URL: http:// www.ons.dz/IMG/ pdf/ Resultats_definitifs_phase_I_RE2011.pdf. Accessed on 09.12.2018

Official Journals of People's Democratic Republic of Algeria (2010), National Spatial Planning Scheme: Synthesis. URL: https:// www.joradp. dz/ FTP/jo-francais/2010/F2010061.pdf. Accessed on 25.01.2018

Paquot, T. (2005), Habitat, habitation, habiter. Ce que parler veut dire... Informations sociales, 3 (128), 48-54. DOI : https:// doi.org/ 10.3917/ inso.123.0048. Accessed on 08.10.2018.

People's Democratic Republic of Algeria (RADP) (2014), National Report on Housing for the Conference on Housing: Habitat III. URL: http:/ / habitat3.org/ wp-content/ uploads/ National-

Report-Africa-Algeria-Final-in-English.pdf. Accessed on 25.04.2019

Planning and Spatial Planning Department of Bouira (2010), Statistical yearbook.

Quicke P. S., Green C. (2017), Precarious residence: Indigenous housing and the right to the city. Geoforum, 85, 167- 177. DOI: https:// doi.org/ 10.1016/j.geoforum. 2017.07.023

Safar-Zitoun M., Hafiane A. (2012), L'entre-deux dans les opérations de relogement en Algérie: L'émergence problématique d'un tiers acteurs urbain (Between the two in the relocation operations in 
Algeria: the problematic emergence in third urban actor). In: Navez-Bouchanine F. (Ed.) Effets sociaux des politiques urbaines. L'entre-deux des politiques institutionnelles et des dynamiques sociales. (The inbetween in relocation operations in Algeria. Social Effects of Urban Policies: The Intersection of Institutional Policies and Social Dynamics), Karthala Edition. Paris, France. ISBN: 9782811106102

Semmoud B. (2009), Appropriations et usages des espaces urbains en Algérie duNord. Appropriations and Uses of Urban Spaces in Northern Algeria. Cahiers de géographie du Québec, 53(148), 101-118. DOI: https:// doi.org/ 10.7202/ 038144ar

Shah S. A., Suzuki H., Hassan M., Saito R., Safian N., Idrus S. (2012), Spatial Analysis of Environmental Factors Influencing Typhoid Endemicity in Kelantan, Malaysia. Sains Malaysiana, 7(41), 911-919. URL: http://journalarticle.ukm.my/ 5306/ 1/ 15\%2520 Shamsul.pdf

Shier M., Graham J . R., Fukuda E., Turner A. (2016), Predictors of Living in Precarious Housing Among Immigrants Accessing Housing Support Services. Journal of International Migration \& Integration, 17, 173-192. DOI: https:// doi.org/ 10.1007/ s12134-014-0396-7

Tebbouche H., Bouchair A., Grimes S. (2017), Towards an environmental approach for the sustainability of buildings in Algeria. Energy Procedia, 119, 98-110. DOI: https://doi.org/10.1016/j.egypro. 2017.07.053
Union Nation Habitat (2003), The challenge of slums: Global report on human settlements. United Nations Human Settlements Program. Earthscan Publications Ltd, London. URL: https:// www.un.org/ ruleoflaw/ files/ Challenge\%20of\%20Slums.pdf.

Accessed on 15.03.2018

Vidal-Naquet P. (2002), La Raison d'État, (The Reason of State), la Découverte. Paris, France. ISBN: 2707136921.

Wetton J . H., Carter R. E., Parkin D. T., Walters D. (1987), Demographic study of a wild house sparrow population by DNA fingerprinting. Nature, 327(6118), 147-149. DOI: https:// doi.org/ 10.1038/327147a0

World Health Organization (WHO) (2017), Leishmaniasis, URL: http://www.who.int/mediacentre / factsheets/ fs375/ en/ . Accessed on 26.07.2017.

Yousfi B. E. (2016), Access to public housing in the Algerian city. Stakeholders' policies, issues and strategies. The case of Tlemcen. Revue française des affaires sociales, 3, 175-206. URL: https:// www.cairnint.info/journal-revue-francaise-des-affaires-sociales2016-3-page-175.htm

Ziersch A., Walsh M., Due C., Duivesteyn E. (2017), Exploring the Relationship between Housing and Health for Refugees and Asylum Seekers in South Australia: A Qualitative Study. International J ournal of Environmental Research and Public Health, 14(9), 220. DOI: https:// doi.org/ 10.3390/ijerph14091036. 